\title{
Ni-Based Coatings for Oil and Gas Industry Fabricated by Cold Gas Spraying ${ }^{\dagger}$
}

\author{
Ekaterina Alekseeva 1,*, Margarita Shishkova 1,*, Darya Strekalovskaya ${ }^{1}$, Dmitry Gerashchenkov ${ }^{2}$ \\ and Pavel Glukhov ${ }^{3}$
}

Citation: Alekseeva, E.; Shishkova, M.; Strekalovskaya, D.; Gerashchenkov, D. Ni-Based Coatings for Oil and Gas Industry Fabricated by Cold Gas Spraying. Mater. Proc. 2021, 3, 2. https://doi.org/10.3390/IEC2M-09388

Academic Editor: Eric D. van Hullebusch

Published: 8 March 2021

Publisher's Note: MDPI stays neutral with regard to jurisdictional claims in published maps and institutional affiliations.

Copyright: (c) 2021 by the authors. Licensee MDPI, Basel, Switzerland. This article is an open access article distributed under the terms and conditions of the Creative Commons Attribution (CC BY) license (http://creativecommons.org/licenses/by/4.0/).
1 Scientific and Technological Complex "New Technologies and Materials", Institute of Advanced Engineering Technologies, Peter the Great Saint-Petersburg Polytechnic University, Polytechnicheskaya 29, 194064 St. Petersburg, Russia; strekal_da@spbstu.ru

2 NRC "Kurchatov Institute"-CRISM “Prometey", 49 Shpalernaya str., 191015 St. Petersburg, Russia; gda.prometey@mail.ru

3 PAO "Severstal", Directorate of Technical Development and Quality, 30 Mira str., 162608 Cherepovets, Russia; pa.glukhov@severstal.com

* Correspondence: alekseeva_el@spbstu.ru (E.A.); shishkova_ml@spbstu.ru (M.S.)

† Presented at the 1st International Electronic Conference on Metallurgy and Metals, 22 February-7 March 2021; Available online: https://iec2m.sciforum.net/.

\begin{abstract}
This paper presents the results of the study of nickel-based coatings fabricated by cold gas spraying. In this study, compositions based on $\mathrm{Ni}, \mathrm{Ni}-\mathrm{Cu}, \mathrm{Ni}-\mathrm{Zn}$, and $\mathrm{Ni}-\mathrm{Al}_{2} \mathrm{O}_{3} / \mathrm{TiC}_{\text {coatings ap- }}$ plied to low-alloyed steel bases were investigated. The composition, type of powder (mechanical mix or mechanically alloying), and thickness varied to choose the optimal characteristics for recovery, repair procedures, and specific applications in the oil and gas industry media. The second phase was added to Ni-based coatings to increase corrosion and wear resistance. Pure nickel coatings were also studied as a benchmark. Corrosion resistance was studied by means of electrochemical testing and autoclave testing in simulated oilfield conditions. Hydroabrasive resistance was studied using a unique testing bench. Scanning electron microscopy mappings, microhardness testing, and adhesion testing were used to correlate the results of the tests with the structure, continuity, and porosity of the studied coatings. It was shown that applying mechanical alloying of the powder did not lead to an effective increase of corrosion and hydroabrasive resistance. All the studied coating specimens have a sufficiently high adhesion. $\mathrm{Ni}-\mathrm{Zn}$ coating has the lowest corrosion resistance and high hydroabrasive resistance. $\mathrm{Ni}-\mathrm{Cu}$ coatings have high corrosion and the lowest hydroabrasive resistance. $\mathrm{Al}_{2} \mathrm{O}_{3} / \mathrm{TiC}$ additives give ambiguous results in the studied properties. A thickness of 40 60 microns provides sufficient performance of the studied coatings. Thus, varying chemical composition and thickness of coatings allows for obtaining the optimal qualities of Ni-based coatings made by cold gas spraying for use in the oil and gas industry.
\end{abstract}

Keywords: Ni-coatings, composite coating; cold gas spraying, oil and gas industry, corrosion, coatings, cold spray coatings; protective coating; hydroabrasive resistance

\section{Introduction}

The aggressive conditions of the oil and gas industry require the use of corrosion-resistant materials for service in chloride-containing media, saturated with hydrogen sulfide and carbon dioxide aqueous solutions containing abrasive particles [1,2]. However, the use of corrosion-resistant steels and alloys is associated with significant capital costs and technical drawbacks; therefore, the use of various types of coatings is becoming increasingly important for the oil and gas industry [3]. At the moment, non-metallic polymer epoxy coatings are widely used for oilfield pipelines, as well as tubing, aluminum, zinc metallization, nickel coatings used for tubing and for more expensive downhole equipment, etc. 
Highly aggressive operating conditions require the use of nickel coatings, since nickel provides corrosion resistance in wide range of conditions, wear resistance, and heat resistance [4]. Nickel-based coatings of various compositions can be applied by various methods: the widespread methods of electrochemical and chemical deposition [5,6], cladding [7,8], thermal spray methods [9-11], chemical vapor deposition [12], and physical vapor deposition [13] methods.

Thermal spray methods allow the obtaining of coatings with various compositions controlled over the thickness of the coating. The method of cold gas dynamic spraying or cold spraying, based on the effect of the formation of a strong metal layer when a twophase supersonic flow hits a normally located surface, is relatively economical, technological, and ecological compared to the above-mentioned methods, and therefore was used in this work [14]. The limitation of this method is the use of mainly ductile materials for spraying, and the fractional composition of no more than 60 microns and a relatively low coefficient of use of powders [15]. The technology finds an application for repair and restoration work, the protection of welding seams, and the restoration of worn surfaces and cracks.

The literature data show that the composition of coatings, presence of additives, and application modes significantly affect the properties of coatings. Thus, there is evidence of increased wear resistance and corrosion resistance when copper is added to a nickel matrix $[16,17]$. Zinc additive provides a high level of adhesion and increased corrosion resistance [18,19]. In several previous studies [19-23], it was shown that the use of modifiers or composite coatings can improve the characteristics of nickel-based coatings. A nickel matrix reinforced with particles like $\mathrm{Al}_{2} \mathrm{O}_{3}, \mathrm{SiC}_{2} \mathrm{ZrO}_{2}$, and $\mathrm{SiO}_{2}$, of nanoscale or micron size, improves the corrosion resistance, wear resistance, and microhardness of steel.

Therefore, the purpose of this work is to study the effect of the chemical composition $\left(\mathrm{Ni}, \mathrm{Ni}-\mathrm{Cu}, \mathrm{Ni}-\mathrm{Zn}, \mathrm{Ni}-\mathrm{Al}_{2} \mathrm{O}_{3}, \mathrm{Ni}-\mathrm{TiC}\right)$ on the corrosion and wear resistance of nickel coatings obtained by the cold gas dynamic spraying (CS) method, in order to assess their applicability in the oil and gas industry.

\section{Materials and Methods}

The deposition of nickel coatings was carried out using the method of cold gas dynamic spraying on a commercially "Dimet-403" installation. To obtain a uniform thickness of the coating on the surface of the substrate, a Kawasaki-FS 003 robot was used, on which the sputtering unit of the Dimet- 403 installation was fixed. The robotic arm also provides a predetermined movement speed in the required interval.

The process of CS includes the following procedures: control of commercially produced gas-atomized powders for chemical and fractional composition, by means of a laser diffraction particle size analyzer (Malvern Zetasizer Nano-ZS and Malvern Mastersizer 2000); preparation of two types of composite powders: a mechanical mixture and a mechanically alloyed powder on an IVCh-3 type attritor installation; heat treatment of powder materials by means of an SNOL-30/1100 Muffle Furnace; sandblasting the surface of the substrate; and applying a powder mixture to a substrate.

The coating was carried out on low carbon steel plates. Mechanical mixtures and mechanically alloyed pure nickel and nickel powders, with the addition of copper and zinc of various concentrations, were used as powders for coating; $\mathrm{Al}_{2} \mathrm{O}_{3}$ and $\mathrm{TiC}$ powder was used to modify the coatings. The compositions and thicknesses of the applied coatings are given in Table 1.

Table 1. Composition and thickness of the applied coatings.

\begin{tabular}{ccc}
\hline Sample & Chemical Composition, wt. $\%$ & Thickness, $\pm 5 \mu$ m \\
\hline Ni90-Cu10/150 & $\mathrm{Ni}=90 \%, \mathrm{Cu}=10 \%$ & 150 \\
$\mathrm{Ni} 90-\mathrm{Cu} 10 / 40$ & $\mathrm{Ni}=90 \%, \mathrm{Cu}=10 \%$ & 40 \\
$\mathrm{Ni60-Cu} 40 / 120$ & $\mathrm{Ni}=60 \%, \mathrm{Cu}=40 \%$ & 120 \\
\hline
\end{tabular}




\begin{tabular}{ccc}
\hline Ni60-Cu40/50 & $\mathrm{Ni}=60 \%, \mathrm{Cu}=40 \%$ & 50 \\
$\mathrm{Ni60}-\mathrm{Zn} 40 / 100$ & $\mathrm{Ni}=60 \%, \mathrm{Zn}=40 \%$ & 100 \\
$\mathrm{Ni60}-\mathrm{Zn} 40 / 200$ & $\mathrm{Ni}=60 \%, \mathrm{Zn}=40 \%$ & 200 \\
$\mathrm{Ni} 90-\mathrm{Zn} 10 / 150$ & $\mathrm{Ni}=90 \%, \mathrm{Zn}=10 \%$ & 150 \\
$\mathrm{Ni} 90-\mathrm{Zn} 10 / 50$ & $\mathrm{Ni}=90 \%, \mathrm{Zn}=10 \%$ & 50 \\
$\mathrm{Ni60}-\mathrm{Al}_{2} \mathrm{O}_{3} 40 / 130$ & $\mathrm{Ni}=60 \%, \mathrm{Al}_{2} \mathrm{O}_{3}=40 \%$ & 130 \\
$\mathrm{Ni60}-\mathrm{Al}_{2} \mathrm{O}_{3} 40 / 60$ & $\mathrm{Ni}=60 \%, \mathrm{Al}_{2} \mathrm{O}_{3}=40 \%$ & 60 \\
$\mathrm{Ni100} / 30$ & $\mathrm{Ni}=100 \%$ & 30 \\
$\mathrm{Ni} 90-\mathrm{TiC} 10$ & $\mathrm{Ni}=90 \%, \mathrm{TiC}=10 \%$ & 70 \\
$\mathrm{Ni60}-\mathrm{TiC} 40$ & $\mathrm{Ni}=60 \%, \mathrm{TiC}=40 \%$ & 70 \\
$\mathrm{Ni50-Cu50-TiC40}(\mathrm{MA})$ & $\mathrm{Ni}=50 \%, \mathrm{Cu}=50 \%$ & 30 \\
Mechanically Alloyed & & \\
\hline
\end{tabular}

\subsection{Corrosion Tests}

Electrochemical corrosion tests were conducted in a three-electrode cell using a Versa stat potentiostat/galvanostat device in $\mathrm{NaCl} 3.0 \mathrm{wt} \%, 2.5 \mathrm{pH}$ solution. The platinum electrode and the saturated calomel electrode (SCE) were used as the counter electrode and the reference electrode, respectively. A potentiodynamic polarization test was carried out with a scan rate of $0.16 \mathrm{mV} \mathrm{s}^{-1}$. The essence of the methodology for calculating the theoretical corrosion rates is based on measuring the polarization resistance of the investigated coatings (working electrode), which makes it possible to calculate the corrosion rates of the test material. Theoretical corrosion rates were calculated using Tafel curves, according to [24].

To assess the corrosion resistance of nickel coatings under simulated operational conditions, the samples were tested in an autoclave in $5.0 \mathrm{wt} \% \mathrm{NaCl}$ solution saturated with hydrogen sulfide $\left(P_{\mathrm{H} 2 \mathrm{~S}}=1 \mathrm{MPa}\right)$ and nitrogen $\left(P_{\mathrm{N} 2}=5 \mathrm{MPa}\right)$ at a temperature of $+80^{\circ} \mathrm{C}$ for $240 \mathrm{~h}$. The autoclave test method in simulated conditions of oil wells is described in detail in Alekseeva et al. [25]. A gravimetric method was used to assess the corrosion rates. Before testing, the samples were weighed with an accuracy up to $0.0001 \mathrm{~g}$, and the edges of the samples were insulated with an epoxy compound. To assess the degradation of coatings, a measurement of the adhesion value before and after tests by the pull-off strength method, according to ASTM D4541 standard, was used.

\subsection{Hydroabrasive Testing}

Evaluation of hydroabrasive wear was carried out on a laboratory test bench installation. Wear assessment was conducted using the gravimetric method. The tests were carried out in water solution, with the addition of $0.5 \mathrm{wt} \%$ quartz with a sand fraction of $0.4-$ $0.8 \mathrm{~mm}$. The testing process consisted of the following processes: the weighing of the test sample; preparation of the test solution by introducing abrasive particles into it; supplying this solution to the surface of the sample in the submerged jet mode, from a distance of 50 $\mathrm{mm}$ and at the angle of $90^{\circ}$, to a sample under a constant circulation of the solution; weighing the sample after testing; and evaluating the results. The method is described in detail in Kovalev et al. [26].

\subsection{Microstructure and Microhardness Investigation}

Scanning electron microscopy using a Tescan VEGA 3 equipped with an Inca X-Max EDS analyzer was used for microstructure and chemical analysis of the studied coatings and powders. The microhardness was measured using a Vickers microhardness tester (ReichertJung Micro-Durmat 4000) with a load of $50 \mathrm{~g}$ applied for $15 \mathrm{~s}$, and was reported as the average of five different readings. Porosity was defined in accordance with ASTM STP947: the sample is immersed in a solution of potassium ferricyanide and sodium chloride, kept for 5 $\mathrm{min}$ at a temperature of $18-30^{\circ} \mathrm{C}$. On the controlled surface, the number of blue dots corresponding to the number of pores is counted. Then, the average number of pores is calculated as the ratio of the number of pores to the area of the controlled surface. 


\section{Results and Discussion}

\subsection{Characterization of Microstructure of Coatings}

Figure 1a illustrates the structure of Ni-Zn coatings with the various ratios of elements. As is shown in the image, the coatings have an even distribution of zinc in the nickel matrix, there are some micro-discontinuities, and no cracks in the structures. Dark "islands" of $\mathrm{Al}_{2} \mathrm{O}_{3}$ with an average size of $2-5$ microns are clearly visible in the structures. This can be seen in the shades of the spectrum (aluminum and oxygen are indicated on the energy dispersive spectrum map together), as well as by size (size of the fraction of aluminum oxide) and shape (aluminum oxide has a fragmented form; pores, on the contrary, are usually round).

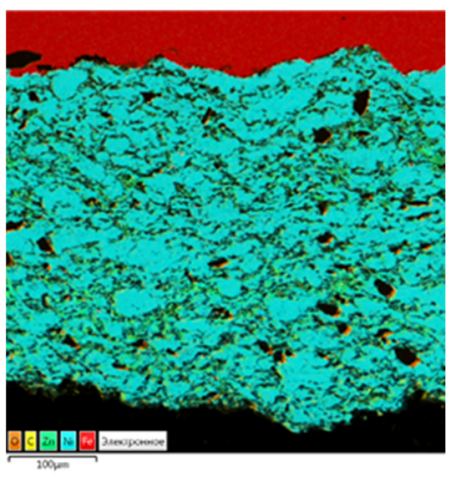

(a)

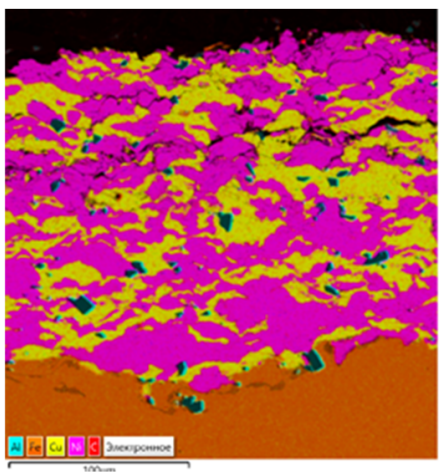

(b)

Figure 1. Ni-Zn coatings: (a) Ni60-Zn40/200 and (b) Ni60-Cu40/120.

Microstructures of the Ni-Cu coatings show cracks in the form of bundles (Figure 1b). Energy-dispersive spectroscopy analysis of the Ni-Cu coatings shows the uneven distribution of $\mathrm{Cu}$ in the nickel matrix. There are randomly distributed dark islands of $\mathrm{Al}_{2} \mathrm{O}_{3}$ in the matrix, as well as in the $\mathrm{Ni}-\mathrm{Zn}$ coatings and the pure Ni samples.

It can be seen from Figure 2a,b that the $\mathrm{TiC}$ reinforcing particles in the Ni matrix are evenly distributed as a separated particle and in the groups of several particles at a size of up to 5 microns. It was found that mechanically alloyed powders (Figure $2 b$ ), which appear in the structure as a separate layer with pores, are difficult to apply. This may be due to the fact that as a result of the powder particle processing, significant work for hardening is happening; in addition, a large amount of oxygen is absorbed by the powder surface.

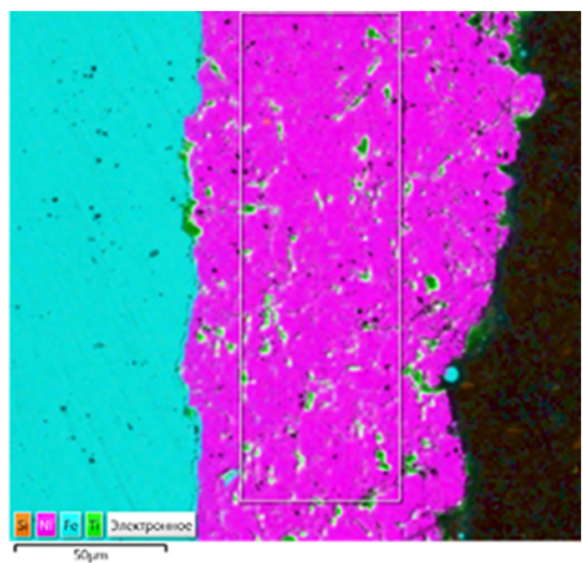

(a)

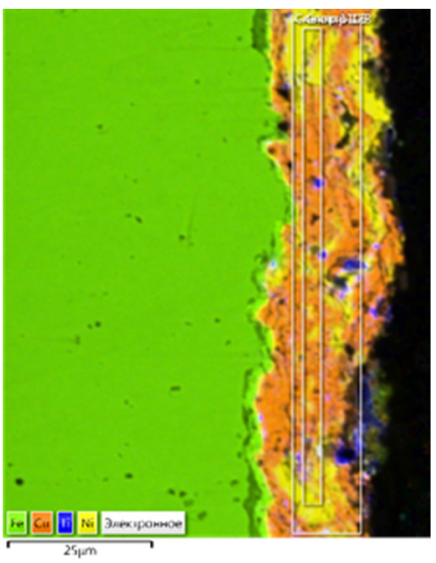

(b)

Figure 2. Nickel coatings with reinforcing particles: (a) Ni60-TiC40 and (b) Ni50-Cu50-TiC40 (MA). 
Porosity and microhardness for types of nickel-based coatings, depending on the chemical composition of these coatings (nickel-copper, nickel-zinc, nickel-reinforcing particles, pure nickel) are shown in Table 2.

Table 2. The average values of porosity and microhardness of the studied types of coatings.

\begin{tabular}{ccc}
\hline Nickel Coating Type & Porosity, Unit $\mathbf{c m}^{\mathbf{2}}$ & Microhardness, $\mathbf{H V}$ \\
\hline $\mathrm{Ni}-\mathrm{Cu}$ & 0.6 & 90 \\
$\mathrm{Ni}-\mathrm{Zn}$ & 2.1 & 170 \\
$\mathrm{Ni}-\mathrm{Al}_{2} \mathrm{O}_{3}$ & 0.5 & 130 \\
$\mathrm{Ni}$ & 1.1 & 185 \\
$\mathrm{Ni}-\mathrm{TiC}$ & 1.1 & 90 \\
$\mathrm{Ni}-\mathrm{Cu}-\mathrm{TiC}(\mathrm{MA})$ & 1.2 & 100 \\
\hline
\end{tabular}

\subsection{Characterization of Corrosion Properties}

Corrosion rates obtained from the polarization curves are given in Figure 3. The samples of $\mathrm{Ni}-\mathrm{Zn}$ coating have the lowest resistance to corrosion; the corrosion rate under test conditions is $2.5-2.6 \mathrm{~mm} /$ year, which is explained by the low corrosion resistance of zinc and its active dissolution under the test conditions, and also by the high porosity of the samples. However, in real conditions, zinc has a protective effect on the nickel matrix, which allows these types of coatings to be successfully used. The samples of $\mathrm{Ni}-\mathrm{Cu}$ and $\mathrm{Ni}-\mathrm{Al}_{2} \mathrm{O}_{3}$ coatings have the higher corrosion resistance: corrosion rates are $0.8-0.9$ $\mathrm{mm} /$ year and $0.5-0.6 \mathrm{~mm} /$ year, respectively, which could be associated with the high corrosion resistance of $\mathrm{Cu}$ and low porosity of the samples. The corrosion resistance of the pure $\mathrm{Ni}$ coating (Ni100/30) was lower than that of the coatings with the addition of $\mathrm{Al}_{2} \mathrm{O}_{3}$, so the presence of these particles enhances corrosion resistance, which could be explained by the low porosity of the samples of $\mathrm{Ni}-\mathrm{Al}_{2} \mathrm{O}_{3}$. It is important to note that the addition of TiC particles and mechanical alloying powder mixture does not increase the corrosion resistance of the coatings.

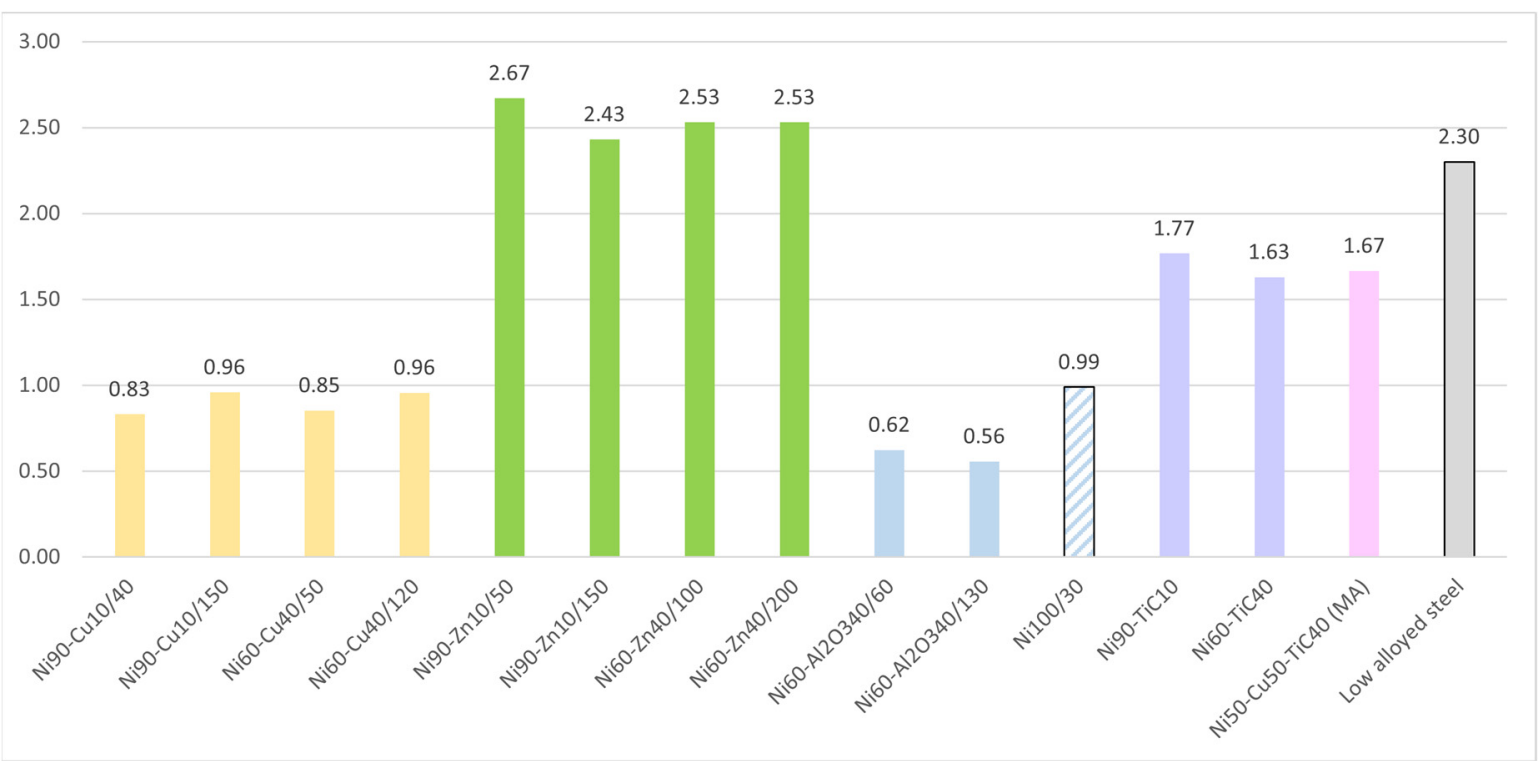

Figure 3. Corrosion rate (in mm per year) of nickel coatings. calculated using electrochemical tests in a $3 \% \mathrm{NaCl}$ solution with $\mathrm{pH}=2.5$.

Results of corrosion testing in the simulated oil and gas media in the autoclave are given in Figure 4. 


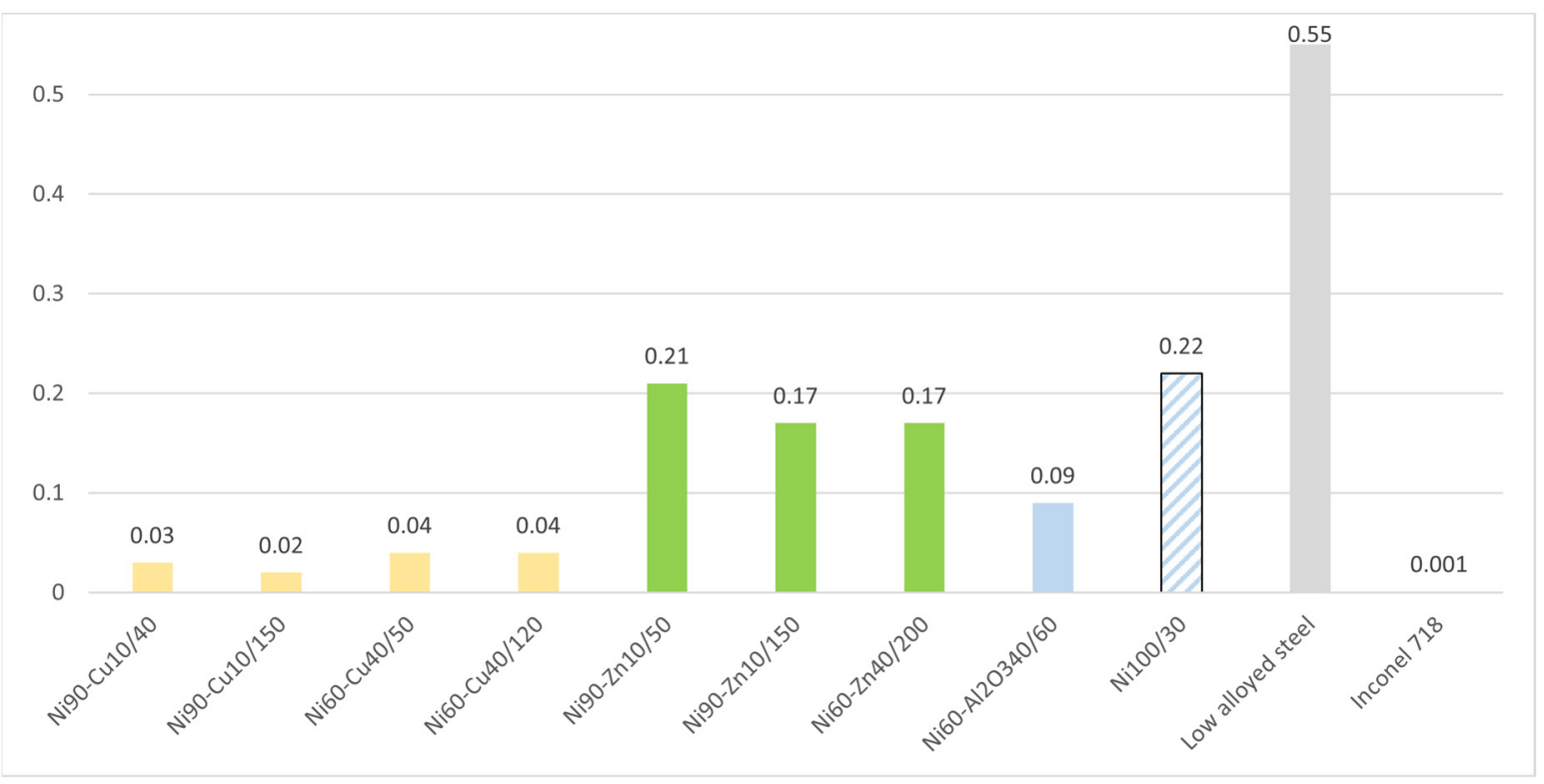

Figure 4. Corrosion rate of nickel coatings in $3 \% \mathrm{NaCl}$ solution with $\mathrm{pH}=2.5$.

The results of autoclave tests are consistent with the results of electrochemical studies: $\mathrm{Ni}-\mathrm{Cu}$ samples demonstrate the highest corrosion resistance under the test conditions, with corrosion rates at $0.02-0.04 \mathrm{~mm} /$ year. However, samples of $\mathrm{Ni}-\mathrm{Al}_{2} \mathrm{O}_{3}$ and $\mathrm{Ni}-\mathrm{Zn}$ have higher corrosion rates, at $0.099 \mathrm{~mm} /$ year and $0.2 \mathrm{~mm} /$ year, respectively. Pure nickel samples showed a low corrosion resistance, due to the low density of the obtained coating.

For comparison, the corrosion rate values for low-alloy steel and Inconel 718 nickelbased alloy are given in Figure 4 . It can be seen that $\mathrm{Ni}-\mathrm{Cu}$ samples have an order of magnitude higher corrosion rate compared to Inconel 718. It can also be seen that, compared with a low-alloy steel, the studied nickel-based coatings provide significant corrosion protection: the corrosion rates with the coatings are 3 to 10 times lower.

All the studied coatings had a sufficiently high adhesion before the autoclave corrosion tests (Table 3), except the mechanically alloyed Ni50-Cu50-TiC40 (MA) sample. The adhesion strength of the coating after the autoclave tests shows a decrease of adhesion by $20-40 \%$ to the initial values.

Table 3. Adhesion strength values before and after the autoclave test.

\begin{tabular}{ccc}
\hline Sample & Adhesion before, MPa & Adhesion after, MPa \\
\hline Ni60-Cu40/50 & 6.36 & 4.04 \\
\hline Ni60-Cu40/120 & 6.61 & 4.40 \\
\hline Ni90-Cu10/150 & 6.82 & 6.41 \\
\hline Ni90-Cu10/40 & 4.83 & 5.87 \\
\hline Ni60-Zn40/100 & 6.65 & 4.50 \\
\hline Ni60-Zn40/200 & 6.24 & 5.25 \\
\hline Ni90-Zn10/150 & 5.72 & 5.36 \\
\hline Ni90-Zn10/50 & 7.81 & 7.54 \\
\hline Ni60-Al2O340/130 & 8.89 \\
\hline Ni100/30 & 9.34 & 7.95 \\
\hline Ni90-TiC10 & 5.85 & 4.70 \\
\hline Ni60-TiC40 & 9.57 & 5.89 \\
\hline Ni50-Cu50-TiC40 (MA) & 7.54 & 4.00 \\
\hline
\end{tabular}




\subsection{Characterization of Wear Properties}

Figure 5 shows the results of hydroabrasive testing in an aqueous solution with 0.5 wt \% quartz sand over 0.5 and $1.0 \mathrm{~h}$. As it can be seen from Figure 5, the microhardness (Table 2) values correlate with the wear resistance of the coatings. The highest resistance to hydroabrasive wear was found in the Ni samples (a microhardness of $185 \mathrm{HV}$ ), Ni-Zn $(170 \mathrm{HV})$, and $\mathrm{Ni}-\mathrm{Al}_{2} \mathrm{O}_{3}$ coatings $(130 \mathrm{HV})$. The $\mathrm{Ni}-\mathrm{Cu}$ samples and the $\mathrm{Ni}-\mathrm{TiC}$ samples had the lowest resistance, due to lower hardness and the presence of discontinuities in the structures. The average weight losses for all investigated samples are $0.02-0.10 \mathrm{~g} / \mathrm{h}$, with the exception of nickel-copper and nickel-corundum coatings.

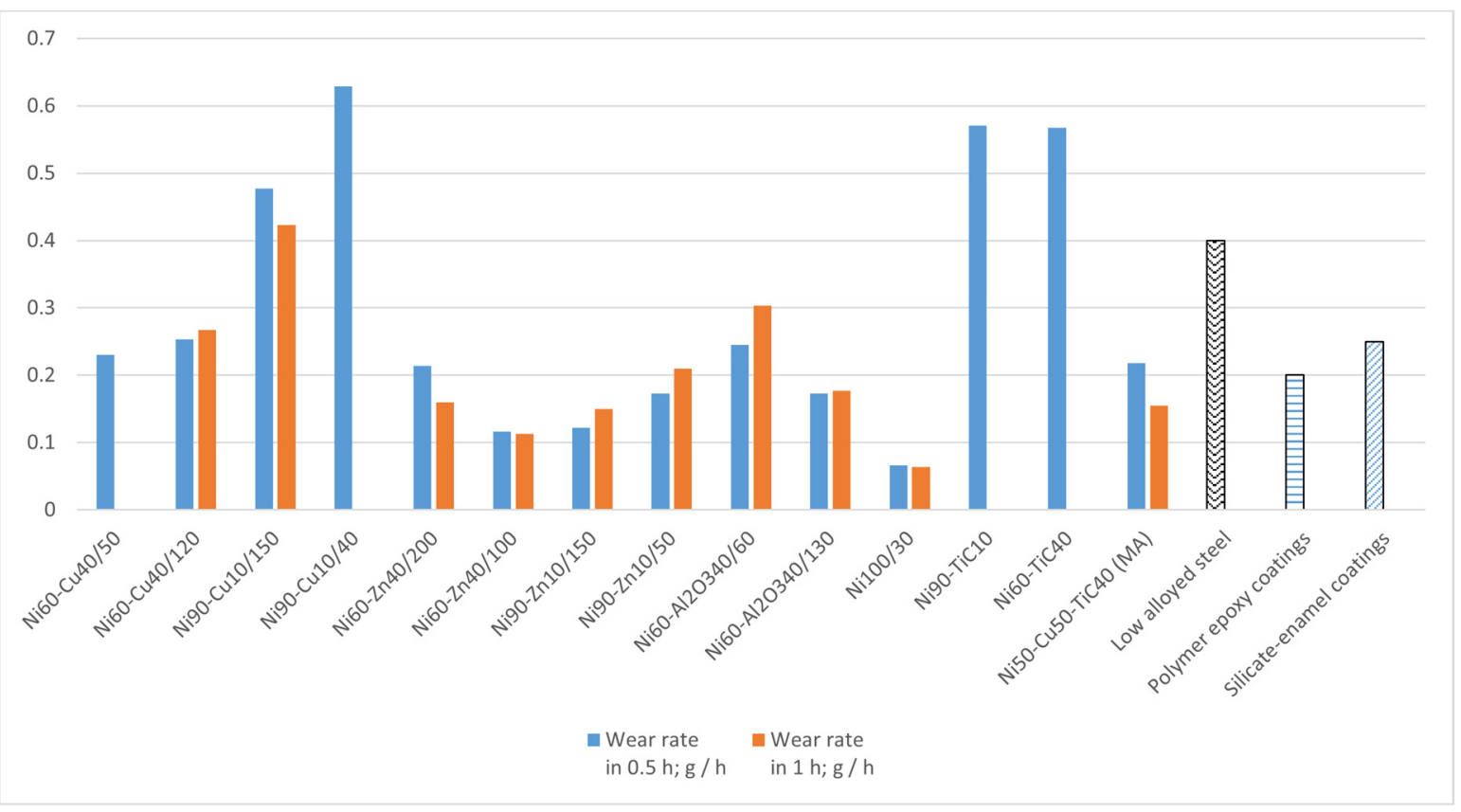

Figure 5. The rate of hydroabrasive wear of coatings for $0.5 \mathrm{~h}$ and $1.0 \mathrm{~h}$.

It is worth noting that according to Kovalev et al. [26], the hydroabrasive wear rates of industrially used coatings for pipelines are $0.15-0.25 \mathrm{~g} / \mathrm{h}$ on average for coatings on a polymer epoxy base and $0.4-0.5 \mathrm{~g} / \mathrm{h}$ for coatings on a silicate-enamel base, while lowalloyed steel pipelines without any coatings have a wear rate of $0.4 \mathrm{~g} / \mathrm{h}$. Thus, the results of tests for resistance to hydroabrasive wear show that nickel-based coatings are more resistant than industrially used, non-metallic coatings.

According to the results of corrosion and hydroabrasive tests, the increase in thickness does not give any improvement, so the thickness of 40 microns is sufficient to protect against corrosion and wear.

\section{Conclusions}

In this study, the samples of nickel-based $\mathrm{Ni}-\mathrm{Zn}, \mathrm{Ni}-\mathrm{Cu}, \mathrm{Ni}-\mathrm{Al}_{2} \mathrm{O}_{3}, \mathrm{Ni}-\mathrm{TiC}$, and $\mathrm{Ni}$ were fabricated by means of cold gas dynamic spraying. Corrosion and wear resistance of the coatings for use in the oil and gas industry were investigated. Our conclusions are as follows:

1. It was shown that the coating based on $\mathrm{Ni}-\mathrm{Zn}$ has the lowest corrosion characteristics (in the simulated oilfield conditions, the corrosion rate is $0.17-0.2 \mathrm{~mm} /$ year), though these coatings have the highest wear resistance characteristics. However, the protective effect of zinc allows them to be used as corrosion-resistant, while at the same time being economically attractive; 
2. The samples of nickel-copper coatings have high corrosion resistance, but low wear resistance due to their low hardness. Applying coatings from mechanically alloyed powders of nickel-copper is not applied practically without titanium carbide;

3. The nickel samples have low resistance to corrosion, but high resistance to hydroabrasive wear;

4. $\mathrm{Al}_{2} \mathrm{O}_{3} / \mathrm{TiC}$ additives give ambiguous results in the studied properties. Specimens with $\mathrm{Al}_{2} \mathrm{O}_{3}$ have a low hydroabrasive wear and high corrosion resistance; the introduction of $\mathrm{TiC}$ particles was not effective in improving these characteristics;

5. All the studied coating specimens have a sufficiently high adhesion before and after testing in autoclave;

6. A thickness of 40-60 microns provides sufficient performance for the studied coatings.

Institutional Review Board Statement: Not applicable

Informed Consent Statement: Not applicable

\section{References}

1. Heidersbach, R. Metallurgy and Corrosion Control in Oil and Gas Production. In Wiley Series in Corrosion, 2nd ed.; John Wiley \& Sons: Hoboken, NJ, USA, 2011; 281p, ISBN 13:9780470248485.

2. Craig, B.D. Oilfield Metallurgy and Corrosion, 3rd ed.; MetCorr: 2014; 335p, ISBN 0615961355.

3. Sankara, P. Corrosion Control in the Oil and Gas Industry; Elsevier: Amsterdam, The Netherlands; Gulf professional Publ.: London, UK, 2013; 1020p, ISBN 9780123970220.

4. Rebak, R.B. Pitting characteristics of nickel alloys-A review. In NACE International Corrosion Conference Proceedings; NACE International: 2016; №7450.

5. MacLean, M.; Farhat, Z.; Jarjoura, G.; Fayyad, E.; Abdullah, A.; Hassan, M. Fabrication and investigation of the scratch and indentation behavior of new generation Ni-P-nano-NiTi composite coating for oil and gas pipelines. Wear 2019, 426-427, $265-$ 276, doi:10.1016/j.wear.2019.01.058.

6. Wang, C.; Farhat, Z.; Jarjoura, G.; Hassan, M.K.; Abdullah, A.M. Indentation and erosion behavior of electroless Ni-P coating on pipeline steel. Wear 2017, 376-377, 1630-1639.

7. Kumar, N.P.; Shanmugam, N.S. Some studies on nickel based Inconel 625 hard overlays on AISI 316L plate by gas metal arc welding based hardfacing process. Wear 2020, 456-457, 203394, doi:10.1016/j.wear.2020.203394.

8. Sahoo, C.K.; Masanta, M. Microstructure and mechanical properties of TiC-Ni coating on AISI304 steel produced by TIG cladding process. J. Mater. Process. Technol. 2017, 240, 126-137.

9. Pawlowski, L. The Science and Engineering of Thermal Spray Coatings, 2nd ed.; John Wiley \& Sons Ltd.: Hoboken, NJ, USA, 2008, doi:10.1002/9780470754085.

10. Brandolt, C.S.; Vega, M.R.O.; Menezes, T.L.; Schroeder, R.M.; Malfatti, C.F. Corrosion behavior of nickel and cobalt coatings obtained by high-velocity oxy-fuel (HVOF) thermal spraying on API 5CT P110 steel. Mater. Corros. 2015, 67, 368-377, doi:10.1002/maco.201508505.

11. Ermakov, B.S.; Alkhimenko, A.A.; Shaposhnikov, N.O.; Ermakov, S.B.; Shatsky, T.E.; Igolkin, A.F. The use of sprayed powders to create coatings in the welds of oilfield pipelines. IOP Conf. Series: Mater. Sci. Eng. 2020, 826, doi:10.1088/1757$899 \times / 826 / 1 / 012008$.

12. Brissonneau, L.; Vahlas, C. Precursors and operating conditions for the metal-organic chemical vapor deposition of nickel films. Annales de Chimie Science des Matériaux 2000, 25, 81-90, doi:10.1016/s0151-9107(00)88716-4.

13. Bowden, C.; Matthews, A. A study of the corrosion properties of PVD Zn-Ni coatings. Surf. Coatings Technol. 1995, 76-77, 508515, doi:10.1016/0257-8972(95)02606-1.

14. Geraschenkov, D.A.; Vasiliev, A.F.; Farmakovsky, B.V.; Mashek, A.C. Study of the flow temperature in the process of cold gasdynamic spraying of functional coatings. Mater. Sci. 2014, 2, 87-96.

15. Gerashchenkov, D.A.; Bobkova, T.I.; Vasiliev, A.F.; Kuznetsov, P.A.; Samodelkin, E.A.; Farmakovsky, B. Functional protective coatings of nickel-based alloys. Vopr. Mater. 2019, 1, 110-114, doi:10.22349/1994-6716-2018-93-1-110-114.

16. Meng, M.; Leech, A.; Le, H. Mechanical properties and tribological behavior of electroless Ni-P-Cu coatings on corrosion-resistant alloys under ultrahigh contact stress with sprayed nanoparticles. Tribol. Int. 2019, 139, 59-66, doi:0.1016/j.triboint.2019.06.031.

17. Li, B.; Mei, T.; Li, D.; Du, S.; Zhang, W. Structural and corrosion behavior of Ni-Cu and Ni-Cu/ZrO2 composite coating electrodeposited from sulphate-citrate bath at low $\mathrm{Cu}$ concentration with additives. J. Alloy. Compd. 2019, 804, 192-201, doi:10.1016/j.jallcom.2019.06.381.

18. Hammami, O. Influence of $\mathrm{Zn}-\mathrm{Ni}$ alloy electrodeposition techniques on the coating corrosion behavior in chloride solution. Surf. Coatings Technol. 2009, 203, 2863-2870. 
19. Shourgeshty, M.; Aliofkhazraei, M.; Karimzadeh, A.; Poursalehi, R. Corrosion and wear properties of $\mathrm{Zn}-\mathrm{Ni}$ and $\mathrm{Zn}-\mathrm{Ni}-\mathrm{Al}_{2} \mathrm{O} 3$ multilayer electrodeposited coatings. Mater. Res. Express 2017, 4, 096406, doi:10.1088/2053-1591/aa87d5.

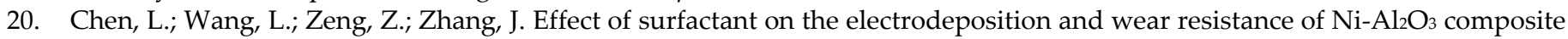
coatings. Mater. Sci. Eng. A 2006, 434, 319-325.

21. Szczygieł, B.; Kołodziej, M. Corrosion resistance of $\mathrm{Ni} / \mathrm{Al}_{2} \mathrm{O}_{3}$ coatings in $\mathrm{NaCl}$ solution. Trans. IMF 2005, 83, 181-187, doi:10.1179/002029605x61658.

22. Ghaziof, S.; Kilmartin, P.A.; Gao, W. Electrochemical studies of sol-enhanced $\mathrm{Zn}-\mathrm{Ni}-\mathrm{Al}_{2} \mathrm{O}_{3}$ composite and $\mathrm{Zn}-\mathrm{Ni}$ alloy coatings. J. Electroanal. Chem. 2015, 755, 63-70, doi:10.1016/j.jelechem.2015.07.041.

23. Oryshchenko, A.S.; Gerashchenkov, D.A. Aluminum matrix functional coatings with high microhardness on the basis of $\mathrm{Al}-$ $\mathrm{Sn}+\mathrm{Al}_{2} \mathrm{O}_{3}$ composite powders fabricated by cold gas dynamic spraying. Inorg. Mater. Appl. Res. 2016, 7, 863-867, doi:10.1134/s2075113316060125.

24. ASTM G3-14 Standard Practice for Conventions Applicable to Electrochemical Measurements in Corrosion Testing. Available online: https://www.astm.org/Standards/G3 (accessed on 1 April 2021).

25. Alekseeva, E.; Galata, L.; Lapechenkov, A.; Kovalev, M. Evaluation of Corrosion Resistance of Nickel-based Alloy EP718 for use in Hydrogen Sulphide Containing Environment. E3S Web Conf. 2021, 225, 03001, doi:10.1051/e3sconf/202122503001.

26. Kovalev, M.; Alekseeva, E.; Shaposhnikov, N. Investigation of hydroabrasive resistance of internal anti-corrosion coatings used in the oil and gas industry. IOP Conf. Series: Mater. Sci. Eng. 2020, 889, 012020, doi:10.1088/1757-899x/889/1/012020. 